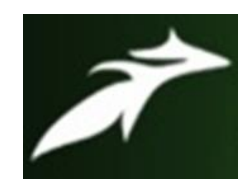

Ramakant Singh Sidar, International Journal of Advances in Agricultural Science and Technology,

Vol.3 Issue.7, December- 2016, pg. 43-50

ISSN: 2348-1358

Impact Factor: 6.057

\title{
Weed Management by Herbicide for Yield and Quality Parameters in Mustard (Brassica juncea L. Czern \& Coss.)
}

\author{
Ramakant Singh Sidar \\ RMD College of Agriculture and Research Station, Indira Gandhi Krishi Vishwavidyalaya \\ Ambikapur, Surguja-497001 (Chhattisgargh) \\ DOI: 10.47856/ijaast.2016.v03i7.001
}

\begin{abstract}
A field experiment on Weed management in herbicide for growth and yield attributing characters in mustard was conducted on the RMD College of Agriculture \& Research Station, Ambikapur, during the Rabi season of 2012-2013. Soil of the experimental field was sandy loam in texture. 12 treatments with different herbicidal combination of weed management practices were study in randomized block design and 3 times replicated. weed control treatments Pendimethalin @ $1.0 \mathrm{~kg} / \mathrm{ha} \mathrm{PE}$, Glyphosate $50 \mathrm{gm} / \mathrm{ha}$ alone after emergence of Orobanche, Trifluralin @ $1.5 \mathrm{~kg} / \mathrm{ha}$ PPI, Glyphosate $25 \mathrm{gm} /$ ha alone with $1 \%$ solution NH4SO4 at 40 DAS, Neem cake at 200kg/ha in furrow and Pendimethalin at $0.5 \mathrm{~kg} / \mathrm{ha}(\mathrm{PE})$ followed by 1 hoeing at $40 \mathrm{DAS}$, Neem cake at $200 \mathrm{~kg} / \mathrm{ha}$ in furrow followed by Imazethapyr $30 \mathrm{gm} / \mathrm{ha}$ at $20 \mathrm{DAS}$, Trifluralin @ $1.5 \mathrm{~kg} / \mathrm{ha}+\mathrm{Neem}$ oil 1\% PPI, soybean oil 2 drops/shoot after emergence of Orobanche, Application of 25\% extra dose of phosphorus and phosphorus solubilizing bacteria, Trichoderma viride $2.5 \mathrm{~kg} / \mathrm{ha}$ as basal application, Farmers practice-1 hoeing at 40DAS and Weedy check, The study of revealed that the plant population was uniform under various weed control treatments. Data pertaining to seed yield $\mathrm{kg} / \mathrm{ha}$. It was clear from the data that application of pendimethalin (T1) produced significantly higher seed yield over all the weed control treatment except treatment T7 and T5. Data further revealed that the treatment T3 also gave significantly higher seed yield over rest the treatment except T1, T5, and T7. Oil content (\%) is analysis of variance revealed that oil content in seed did not differ significantly among different weed control treatments. However, it varied from 39.80 to 40.52 per cent. The maximum oil yield was recorded in treatment T1 which was significantly higher over weedy check. All the weed control treatments noted higher oil yield over weedy check.
\end{abstract}

Keywords: Mustard, Weed management, Herbicide Combinations

\section{INTRODUCTION:}

Indian mustard [Brassica juncea (L.) Czern \& Cross] is one of the oil seed crop of the state of Madhya Pradesh. The problem of low productivity continues to be a major issue for agricultural planners and researchers. The best way to increase the productivity of mustard is by improving crops. Weeds are regarded as one of the major negative factors of crop produce loss 


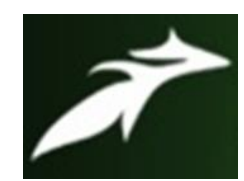

Ramakant Singh Sidar, International Journal of Advances in Agricultural Science and Technology, Vol.3 Issue.7, December- 2016, pg. 43-50

due to competition for nutrient, moisture, light and space which have been reported as high as 30-70\% (Tiwari,1998).

Mustard crop is grown both in subtropical and temperate countries. India occupies the third position with regard to average production of rapeseed and mustard in the world. It is raised to 5.77 million hectares with an annual production of 6.59 million tonnes and average productivity of $1142 \mathrm{~kg} / \mathrm{ha}$ in the country. In Madhya Pradesh rapeseed and mustard is grown in 791 thousand hectares area with annual production of 849 thousand tonnes and average productivity of 1075 $\mathrm{kg} / \mathrm{ha}$. But in Gwalior district it covers an area of 58.5 thousand hectares with annual production 75.9 thousand tonnes and average productivity of $1303 \mathrm{~kg} / \mathrm{ha}$ (CLRS M.P., 2009-10). Many workers have stated that glyphosate at lower rates $(82 \mathrm{~g} / \mathrm{ha})$ 30DAS provided excellent control of broomrape without any toxic effect on mustard crop, but it caused some toxicity at higher rates (123 g/ha) 60DAS to the crop. Other herbicides like fluchloralin and pendimethalin did not control this weed (Kumar, 2002).

The mustard crop is infested with grassy as well as broadleaf weeds. Weeds substantially reduce the productivity and production of mustard due to competition for various inputs. A wide ranging yield reduction in the crop on account of weeds is well documented. Therefore, there is a need to create an environment that is detrimental to weeds and favourable to crop. (Bhan 1992, Banga and Yadav, 2001 and Singh et al. 2001) even ranging from 20-70\% depending upon the type of weed flora, magnitude and duration of weed infestation (Tiwari and Kurchania 1993) Competition by weeds at initial stages is a major limiting factor to its productivity.

\section{MATERIALS AND METHODS:}

The field experiment was carried out during Rabi season of 2012-2013 at the Research farm, RMD College of Agriculture \& Research Station, Ambikapur situated at 23018' $\mathrm{N}$ latitude and 83015' Elongitude and at altitude of 611 meter above mean sea level which represents the northern hills agro-climatic zone of Chhattisgarh. The soil of the experimental site was sandy loam in texture, acidic in reaction $(\mathrm{pH} 5.7)$, medium in organic carbon (0.56), available nitrogen (234 kg ha-1), available phosphorus ( $8.4 \mathrm{~kg}$ ha-1) and available potassium (268 $\mathrm{kg}$ ha-1). The experiment was carried out in randomized block design (RBD) with 3 replications. The treatments contained of nine weed management practices. The treatment comprised of Pendimethalin @ 1.0kg/ha PE, Glyphosate 50gm/ha alone after emergence of Orobanche, Trifluralin @ 1.5kg/ha PPI, Glyphosate 25gm/ha alone with $1 \%$ solution NH4SO4 at 40 DAS, Neem cake at $200 \mathrm{~kg} / \mathrm{ha}$ in furrow and Pendimethalin at $0.5 \mathrm{~kg} / \mathrm{ha}$ (PE) followed by 1 hoeing at $40 \mathrm{DAS}$, Neem cake at $200 \mathrm{~kg} / \mathrm{ha}$ in furrow followed by 


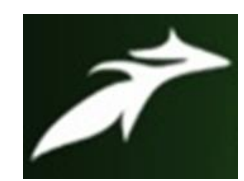

Ramakant Singh Sidar, International Journal of Advances in Agricultural Science and Technology, Vol.3 Issue.7, December- 2016, pg. 43-50

Imazethapyr 30gm/ha at 20DAS, Trifluralin @ 1.5kg/ha +Neem oil 1\% PPI, Soybean oil 2 drops I shoot after emergence of Orobanche, Application of 25\% extra dose of phosphorus and phosphorus solubilizing bacteria, Trichoderma viride $2.5 \mathrm{~kg} / \mathrm{ha}$ as basal application, Farmers practice-1 hoeing at 40DAS and Weedy check. Data on weed population were recorded at 30, 60 days after sowing and at harvest. The observations of weed density and their dry matter were taken randomly from $0.25 \mathrm{~m} 2$ quadrate from net plot area from each treatment. To calculate the weed control Data on weed density and dry weight was subjected to square root transformation before analysis.

\section{RESULTS AND DISCUSSION: Yield attributing characters Number of siliquae per plant}

Analysis of variance indicated that weed control treatment exerted significant influence on this yield attributing character. It is obvious from the data (Table 1) that number of siliquae per plant showed a positive response to most of the weed control measures. Among all the weed control treatments, T1 recorded significantly higher number of siliquae per plant, but it was at par with T7 and both are significantly over rest of the treatments. Minimum number of siliquae per plant (171.06) was registered with weedy check which was at par with T6.The treatments T8, T9, T10 and T11 also recorded statistically similar siliquae per plant and significantly higher siliquae per plant over weedy check and T6

\section{Length of siliqua (cm)}

The analysis of variance on length of siliqua at harvest is given in where it was observed that effect of treatments on length of siliquae was significant. The highest length of siliquae (3.95 $\mathrm{cm}$ ) was recorded in $\mathrm{T} 1$ treatment, which was at par with T7, T5 and T3 treatment and significantly superior over rest of the treatments including weedy check. The minimum length of siliqua $(2.99 \mathrm{~cm})$ was recorded in T6 followed by T8, T9, T10, and T11 treatments (Table 1).

\section{Seeds per siliqua}

Weed management practices improved the number of seeds per siliquae of mustard (Table 1). Highest numbers of seeds per siliquae was recorded under T1 which was at par with T7, T5 and T3. They are significantly superior over weedy check \& T6. Treatments T2, T4, T8, T9, T10 and T11 are not reached to the levels of significant but they are statistically at par to each other and significantly superior over $\mathrm{T} 6$. 


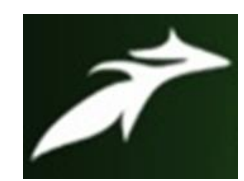

Ramakant Singh Sidar, International Journal of Advances in Agricultural Science and Technology, Vol.3 Issue.7, December- 2016, pg. 43-50

\section{Seed weight (g/plant)}

All the weed control treatment recorded significantly higher in seed weight per plant as compared to weedy check and T9 (Table 2).Treatment T1 gave significantly higher seed weight per plant over weedy check and T9 and at par with T7 \& T5. Similarly treatment T2, T3, T4, T6, T8, T10 and T11 were also statistically at par in respect of seed weight per plant. They were also superior to weedy check and T9.

\section{0 seed weight $(\mathrm{g})$}

All the weed control treatments produced significantly higher 1000 seed weight over weedy check except T6 and T9. Application of pendimethalin registered significantly higher 1000 seed weight over weedy check, T6 \& T9 but at par with T7, T5 and T3. Remaning treatment were also at par. Similresults were reported by Singh et al. (2001), Kataria et al. (2003), Sharma et al. (2005).

\section{Yield parameters}

\section{Seed yield $(\mathrm{kg} / \mathrm{ha})$}

Data pertaining to seed yield $\mathrm{kg} / \mathrm{ha}$ are presented in table 3 It was clear from the data that application of pendimethalin (T1) produced significantly higher seed yield over all the weed control treatment except treatment T7 and T5. Data further revealed that the treatment T3 also gave significantly higher seed yield over rest the treatment except $\mathrm{T} 1, \mathrm{~T} 5$, and $\mathrm{T} 7$.

\section{Stover yield (kg/ha)}

The data on stover yield $(\mathrm{kg} / \mathrm{ha}$ ) presented in Table 3 Further it clear from the data (table 4.9) that maximum stover yield $(\mathrm{kg} / \mathrm{ha})$ under $\mathrm{T} 1$ which was significantly higher over weedy check and T6 but at par with T7 and T5. Similarly treatment T3, T2, T4, T8, T9, T10 and T11 produced significantly higher stover yield over weedy check and T6 and they were statistically at par to each others.

\section{Quality parameters}

\section{Oil content (\%)}

Analysis of variance revealed that oil content in seed did not differ significantly among different weed control treatments. However, it varied from 39.80 to 40.52 per cent (Table-4).

\section{Oil Yield (kg/ha)}

The maximum oil yield was recorded in treatment $\mathrm{T} 1$ which was significantly higher over weedy check. All the weed control treatments noted higher oil yield over weedy check. Similar results were reported by Singh et al. (2001), Kataria et al. (2003) and Sharma et al. (2005). 


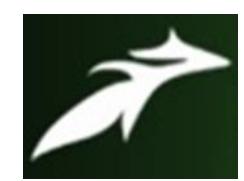

Ramakant Singh Sidar, International Journal of Advances in Agricultural Science and Technology,

Vol.3 Issue.7, December- 2016, pg. 43-50

ISSN: 2348-1358

Impact Factor: 6.057

\section{References:}

[1]. Banga R.S. and Yadav, A. (2001). Evaluation of herbicides against complex weed flora in Indian mustard. Haryana Journal of Agronomy: 17:48-51.

[2]. Bhan V.M. (1992). Weed management a factor for sustainability in crop production In: Proceeding of XII National Symposium on Resource Management for Sustained Crop Production, held At Rajasthan Agriculture University, Bikaner, 209-2016.

[3]. Kataria, O.P., Chauhan, D.R. and Balyan, R.S. (2003). Effect of herbicides on weeds and seed yield of tobacco (Nicotiana tobacum L.). Indian J. Weed Sci. 35 (1/2): 151-152.

[4]. Meena, M. L. and Dinesh Sah (2011). Effect of weed control and fertilization on yield attributes and seed yield of mustard (Brassic juncea L.) under western plains of UP. Environment and Ecology;. 29: (2A), 929-931. 5.

[5]. Sharma, S.K., Singh, Vireshwar and Panwar, K.S. (2005). Weed management in Indian mustard (Brassica juncea) under dryland conditions. Indian J Agric. Sci. 75 (5): 288-289.

[6]. Singh SS. (1992). Effect of fertilizer application and weed control on the yield of mustard (Brassica juncea). Indian Journal of Agronomy.; 37:196-198.

[7]. Singh.; Harphool., Singh, B.P. and Prasad, Hanuman. (2001). Weed management in Brassica species. Indian J. Agron. 46 (3): 533-537.

[8]. Tiwari J.P. and Kurchania, S.P. (1993). Chemical control of weeds in Indian mustard (Brassica juncea L.). Indian Agricultural Sciences; 63:272-275.

Table.1. Number of siliquae per plant, length of siliqua and number of seeds per siliqua of mustard as influenced by different weed control measures

\begin{tabular}{|c|c|c|c|c|}
\hline S. No. & Treatment & $\begin{array}{l}\text { Siliquae/ } \\
\text { plant }\end{array}$ & $\begin{array}{l}\text { Length } \\
\text { of siliqua } \\
\text { (cm) }\end{array}$ & $\begin{array}{l}\text { Seeds/ } \\
\text { siliqua }\end{array}$ \\
\hline & & 277.53 & 3.95 & 15.16 \\
\hline 2 & $\begin{array}{l}\mathrm{T}_{2-} \text { Glyphosate } 50 \mathrm{gm} / \text { ha alone after emergence of } \\
\text { Orobanche }\end{array}$ & 217.23 & 3.68 & 12.93 \\
\hline 3 & $\mathrm{~T}_{3}$ - Trifluralin @ 1.5kg/ha PPI & 240.50 & 3.84 & 13.83 \\
\hline 4 & $\begin{array}{l}\mathrm{T}_{4} \text { - Glyphosate } 25 \mathrm{gm} / \text { ha alone with } 1 \% \text { solution } \\
\mathrm{NH} 4 \mathrm{SO} 4 \text { at } 40 \mathrm{DAS}\end{array}$ & 229.70 & 3.75 & 13.16 \\
\hline 5 & $\begin{array}{l}\mathrm{T}_{5} \text { - Neem cake at } 200 \mathrm{~kg} / \mathrm{ha} \text { in furrow and } \\
\text { Pendimethalin at } 0.5 \mathrm{~kg} / \mathrm{ha}(\mathrm{PE}) \text { followed by } 1 \text { hoeing } \\
\text { at } 40 \mathrm{DAS}\end{array}$ & 246.76 & 3.86 & 13.90 \\
\hline 6 & $\begin{array}{l}\mathrm{T}_{6} \text { - Neem cake at } 200 \mathrm{~kg} / \mathrm{ha} \text { in furrow followed by } \\
\text { Imazethapyr } 30 \mathrm{gm} / \mathrm{ha} \text { at } 20 \mathrm{DAS}\end{array}$ & 180.66 & 2.99 & 10.73 \\
\hline 7 & $\mathrm{~T}_{7-}$ Trifluralin @ 1.5kg/ha +Neem oil 1\% PPI & 252.86 & 3.87 & 14.70 \\
\hline 8 & $\begin{array}{l}T_{8} \text { - soybean oil } 2 \text { drops / shoot after emergence of } \\
\text { Orobanche }\end{array}$ & 195.73 & 3.58 & 12.76 \\
\hline
\end{tabular}




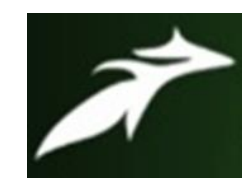

Ramakant Singh Sidar, International Journal of Advances in Agricultural Science and Technology, Vol.3 Issue.7, December- 2016, pg. 43-50

ISSN: 2348-1358

Impact Factor: 6.057

\begin{tabular}{|c|c|c|c|c|}
\hline 9 & $\begin{array}{l}\mathrm{T}_{9} \text { - Application of } 25 \% \text { extra dose of phosphorus } \\
\text { and phosphorus solubilizing bacteria }\end{array}$ & 190.86 & 3.56 & 12.73 \\
\hline 10 & $\begin{array}{l}\mathrm{T}_{10} \text { - Trichoderma viride } 2.5 \mathrm{~kg} / \mathrm{ha} \text { as basal } \\
\text { application }\end{array}$ & 201.13 & 3.58 & 12.90 \\
\hline 11 & $\mathrm{~T}_{11}$ - Farmers practice-1 hoeing at 40DAS & 207.86 & 3.61 & 12.90 \\
\hline 12 & $\mathrm{~T}_{12}$ - Weedy check & 171.06 & 3.46 & 12.10 \\
\hline & S.E.m \pm & 2.249 & 0.057 & 0.56 \\
\hline
\end{tabular}

Table.2. Seed and 1000 seed weight of mustard as influenced by different weed control measures

\begin{tabular}{|c|c|c|c|}
\hline S. No. & Treatment & $\begin{array}{l}\text { Seed } \\
\text { weight } / p l \\
\text { ant }(\mathrm{g})\end{array}$ & $\begin{array}{l}\text { 1000 Seed } \\
\text { weight } \\
\text { (g) }\end{array}$ \\
\hline 1 & T1-Pendimethalin @ 1.0kg/ha PE & 19.23 & 4.760 \\
\hline 2 & $\begin{array}{l}\mathrm{T}_{2} \text { - Glyphosate } 50 \mathrm{gm} / \mathrm{ha} \text { alone after emergence of } \\
\text { Orobanche }\end{array}$ & 16.40 & 4.180 \\
\hline 3 & $\mathrm{~T}_{3}$ - Trifluralin @ 1.5kg/ha PPI & 17.38 & 4.586 \\
\hline 4 & $\begin{array}{l}\mathrm{T}_{4} \text { - Glyphosate } 25 \mathrm{gm} / \mathrm{ha} \text { alone with } 1 \% \text { solution } \\
\mathrm{NH} 4 \mathrm{SO} 4 \text { at } 40 \mathrm{DAS}\end{array}$ & 16.73 & 4.296 \\
\hline 5 & $\begin{array}{l}T_{5^{-}} \text {Neem cake at } 200 \mathrm{~kg} / \mathrm{ha} \text { in furrow and } \\
\text { Pendimethalin at } 0.5 \mathrm{~kg} / \mathrm{ha}(\mathrm{PE}) \text { followed by } 1 \text { hoeing } \\
\text { at } 40 \text { DAS }\end{array}$ & 18.37 & 4.523 \\
\hline 6 & $\begin{array}{l}\mathrm{T}_{6} \text { - Neem cake at } 200 \mathrm{~kg} / \mathrm{ha} \text { in furrow followed by } \\
\text { Imazethapyr } 30 \mathrm{gm} / \mathrm{ha} \text { at } 20 \mathrm{DAS}\end{array}$ & 16.38 & 3.910 \\
\hline 7 & $\mathrm{~T}_{7}$ - Trifluralin @ $1.5 \mathrm{~kg} / \mathrm{ha}+$ Neem oil $1 \%$ PPI & 18.96 & 4.600 \\
\hline 8 & $\begin{array}{l}\mathrm{T}_{8} \text { - soybean oil } 2 \text { drops / shoot after emergence of } \\
\text { Orobanche }\end{array}$ & 15.19 & 4.016 \\
\hline 9 & $\begin{array}{l}T_{9}-\text { Application of } 25 \% \text { extra dose of phosphorus } \\
\text { and phosphorus solubilizing bacteria }\end{array}$ & S14.65 & 3.956 \\
\hline 10 & $\begin{array}{l}\mathrm{T}_{10} \text { - Trichoderma viride } 2.5 \mathrm{~kg} / \mathrm{ha} \text { as basal } \\
\text { application }\end{array}$ & 15.50 & 4.056 \\
\hline 11 & $\mathrm{~T}_{11}$ - Farmers practice- 1 hoeing at 40DAS & 16.16 & 4.100 \\
\hline \multirow[t]{3}{*}{12} & $\mathrm{~T}_{12}$ - Weedy check & 13.99 & 3.820 \\
\hline & S.E.m \pm & $\mathbf{0 . 3 3}$ & 0.068 \\
\hline & C.D. at $5 \%$ & 0.97 & 0.202 \\
\hline
\end{tabular}




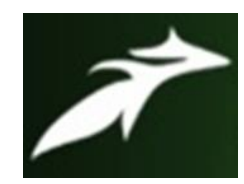

Ramakant Singh Sidar, International Journal of Advances in Agricultural Science and Technology,

Vol.3 Issue.7, December- 2016, pg. 43-50

ISSN: 2348-1358

Impact Factor: 6.057

Table.3. Seed and stover yield of mustard as influenced by weed control measures

\begin{tabular}{|c|c|c|c|}
\hline S. No. & Treatment & $\begin{array}{l}\text { Seed yield } \\
(\mathrm{kg} / \mathrm{ha})\end{array}$ & $\begin{array}{l}\text { Stover } \\
\text { yield } \\
\text { (kg/ha) }\end{array}$ \\
\hline 1 & T1-Pendimethalin@ 1.0kg/ha PE & 2222.22 & 6527.77 \\
\hline 2 & $\begin{array}{l}\mathrm{T}_{2} \text { - Glyphosate } 50 \mathrm{gm} / \mathrm{ha} \text { alone after emergence of } \\
\text { Orobanche }\end{array}$ & 1851.85 & 5185.18 \\
\hline 3 & $\mathrm{~T}_{3}$-Trifluralin@1.5kg/ha PPI & 2025.46 & 5370.36 \\
\hline 4 & $\begin{array}{l}\mathrm{T}_{4} \text { - Glyphosate } 25 \mathrm{gm} / \mathrm{ha} \text { alone with } 1 \% \text { solution } \\
\mathrm{NH} 4 \mathrm{SO} 4 \text { at } 40 \mathrm{DAS}\end{array}$ & 1863.42 & 5243.05 \\
\hline 5 & $\begin{array}{l}\mathrm{T}_{5^{-}} \text {Neem cake at } 200 \mathrm{~kg} / \mathrm{ha} \text { in furrow and } \\
\text { Pendimethalin at } 0.5 \mathrm{~kg} / \mathrm{ha}(\mathrm{PE}) \text { followed by } 1 \text { hoeing } \\
\text { at } 40 \mathrm{DAS}\end{array}$ & 2106.47 & 5995.36 \\
\hline 6 & $\begin{array}{l}\mathrm{T}_{6} \text { - Neem cake at } 200 \mathrm{~kg} / \mathrm{ha} \text { in furrow followed by } \\
\text { Imazethapyr } 30 \mathrm{gm} / \mathrm{ha} \text { at } 20 \mathrm{DAS}\end{array}$ & 1635.64 & 4747.68 \\
\hline 7 & $\mathrm{~T}_{7^{-}}$Trifluralin @ 1.5kg/ha +Neem oil 1\% PPI & 2141.20 & 6423.60 \\
\hline 8 & $\begin{array}{l}\mathrm{T}_{8} \text { - soybean oil } 2 \text { drops / shoot after emergence of } \\
\text { Orobanche }\end{array}$ & 1747.68 & 5126.64 \\
\hline 9 & $\begin{array}{l}\mathrm{T}_{9-} \text { - Application of } 25 \% \text { extra dose of phosphorus } \\
\text { and phosphorus solubilizing bacteria }\end{array}$ & 1712.96 & 5115.73 \\
\hline 10 & $\begin{array}{l}\mathrm{T}_{10} \text { - Trichoderma viride } 2.5 \mathrm{~kg} / \mathrm{ha} \text { as basal } \\
\text { application }\end{array}$ & 1840.27 & 5138.88 \\
\hline 11 & $\mathrm{~T}_{11}$ - Farmers practice- 1 hoeing at $40 \mathrm{DAS}$ & 1851.84 & 5208.33 \\
\hline \multirow[t]{3}{*}{12} & $T_{12}$ - Weedy check & 1643.51 & 4652.77 \\
\hline & S.E.m \pm & 45.39 & 184.92 \\
\hline & C.D. at 5\% & 133.13 & 542.38 \\
\hline
\end{tabular}

Table.4. Oil content and oil yield of mustard as influenced by different weed control measures

\begin{tabular}{|l|l|l|l|}
\hline S. No. & Treatment & $\begin{array}{l}\text { Oil } \\
\text { content } \\
(\mathbf{\%})\end{array}$ & $\begin{array}{l}\text { Oil yield } \\
\mathbf{( k g / h a )}\end{array}$ \\
\hline 1 & $\begin{array}{l}\text { T1- Pendimethalin @ 1.0kg/ha PE } \\
40.34\end{array}$ & 896.44 \\
\hline 2 & $\begin{array}{l}\mathrm{T}_{2} \text { - Glyphosate 50gm/ha alone after emergence of } \\
\text { Orobanche }\end{array}$ & 40.25 & 750.02 \\
\hline 3 & $\mathrm{~T}_{3}$ - Trifluralin @ 1.5kg/ha PPI & 40.52 & 820.71 \\
\hline 4 & $\begin{array}{l}\mathrm{T}_{4} \text { - Glyphosate 25gm/ha alone with 1\% solution } \\
\text { NH4SO4 at 40 DAS }\end{array}$ & 39.95 & 739.81 \\
\hline & & & \\
\hline
\end{tabular}




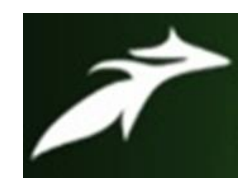

Ramakant Singh Sidar, International Journal of Advances in Agricultural Science and Technology,

Vol.3 Issue.7, December- 2016, pg. 43-50

ISSN: 2348-1358

Impact Factor: 6.057

\begin{tabular}{|c|c|c|c|}
\hline 5 & $\begin{array}{l}\mathrm{T}_{5} \text { - Neem cake at } 200 \mathrm{~kg} / \mathrm{ha} \text { in furrow and } \\
\text { Pendimethalin at } 0.5 \mathrm{~kg} / \mathrm{ha}(\mathrm{PE}) \text { followed by } 1 \text { hoeing } \\
\text { at } 40 \mathrm{DAS}\end{array}$ & 40.42 & 851.43 \\
\hline 6 & $\begin{array}{l}\mathrm{T}_{6}-\text { Neem cake at } 200 \mathrm{~kg} / \mathrm{ha} \text { in furrow followed by } \\
\text { Imazethapyr } 30 \mathrm{gm} / \mathrm{ha} \text { at } 20 \mathrm{DAS}\end{array}$ & 40.01 & 654.41 \\
\hline 7 & $\mathrm{~T}_{7-}$ Trifluralin@1.5kg/ha +Neem oil 1\% PPI & 40.20 & 860.76 \\
\hline 8 & $\begin{array}{l}\mathrm{T}_{8} \text { - soybean oil } 2 \text { drops / shoot after emergence of } \\
\text { Orobanche }\end{array}$ & 39.82 & 695.92 \\
\hline 9 & $\begin{array}{l}\mathrm{T}_{9-} \text { Application of } 25 \% \text { extra dose of phosphorus } \\
\text { and phosphorus solubilizing bacteria }\end{array}$ & 40.09 & 686.72 \\
\hline 10 & $\begin{array}{l}\mathrm{T}_{10^{-}} \text {Trichoderma viride } 2.5 \mathrm{~kg} / \mathrm{ha} \text { as basal } \\
\text { application }\end{array}$ & 39.91 & 734.45 \\
\hline 11 & $\mathrm{~T}_{11}$ - Farmers practice- 1 hoeing at 40DAS & 40.11 & 742.77 \\
\hline \multirow[t]{3}{*}{12} & $\mathrm{~T}_{12}$ - Weedy check & 39.80 & 654.11 \\
\hline & S.E.m \pm & 0.318 & 1.57 \\
\hline & C.D. at $5 \%$ & NS & 4.61 \\
\hline
\end{tabular}

